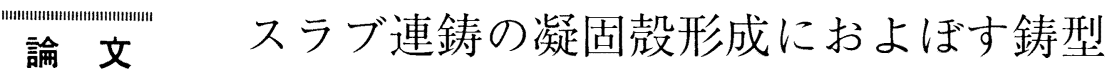

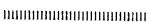 緩冷却化の影響
}

\author{
中井 健*・坂下勉 $* 2 \cdot$ 橋尾 守規*2 \\ 川崎 守夫**中島 敬治*・杉谷 泰夫*
}

\section{Effect of Mild Cooling in Mould upon Solidified Shell Formation of Continuously Cast Slab}

Ken NAKaI, Tsutomu SAKaSHITA, Moriki HASHIO, Morio KaWASAKI, Keiji NAKAJIMA and Yasuo SUGITANI

\begin{abstract}
Synopsis:
The effect of reducing heat flux density in continuous casting mould on the solidified shell formation has been studied in order to improve the irregularity of solidified shell thickness and to reduce longitudinal surface cracks. From theoretical considerations, mild cooling in the mould can be attained by making many grooves on the mould inner surface, since the heat transfer coefficient between the strand shell and the mould is lowered due to the air gap existence in the groove. Therefore the width of each groove should be minimized to prevent the molten powder from flowing into the groove.

Experiments using the mould with small longitudinal grooves have been carried out in the curved continuous casting machine. From results of temperature measurements in the copper mould, the local heat flux density at $15 \mathrm{~mm}$ below the mould meniscus is lowered to about two thirds of that of the conventional smooth surface mould. Both the irregularity of shell thickness and the surface quality of slabs are considerably improved.
\end{abstract}

\section{1. 緒言}

連続鋳造において鋳型メニスカス付近の初期凝固を制 御することは, 表面疵防止の観点から極めて重要である. 縦割れ、コーナー縦割れ等は鋳型内ですでに割れが発生

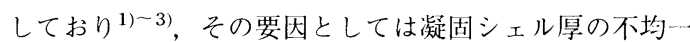
が挙げられる。

凝固シェル厚の不均一生成に関与する因子としては, 鋼の炭素濃度 ${ }^{4)-6)}$, パウダー物性 (7)-10) 抢よび鋳型内抜 熱量の三つが考えられる。鋳型内抜熱量の低減により中 炭素鋼 $(0.10 \sim 0.15 \% \mathrm{C})$ の初期凝固シェル厚の均一化 が図れることは，著者らの一人がすでに報告してい る ${ }^{11)}$.すなわち抜熱量を通常の $2 / 3$ 以下とすることで不 均一度が大幅に改善される。

このように鋳型の緩冷却化は初期凝固改善に有効であ るとされていたが，実用化手段の選定が困難であり，現 在まで実操業への適用はほとんどなされていなかつた。
連鋳鋳型表面に関する緩冷却化の才法としては，次の二 つが考えられる。i）鋳型材質の低熱伝導率化あるいは 鋳型銅板表面への低熱伝導物質の溶射やめつき，ii）鋳 型表面の凹凸化．i）の力法は問題点として溶鋼に接す る面の温度上昇があり鋳型と凝湖シェル問の焼つきが生 じやすい，溶射やめつきの場合は，制離あるいはき裂が 生じやすい.したがつてこのうう法は実機への適用には難 点を有する。 ii ) の方法については、ショットブラスト による銅板表面の凹凹化 ${ }^{12)}$ あるいは湄を加】する方 法 ${ }^{13)}$ が報告されている，操業安起性では，ii）の方法 がすぐれていると考えられる。しかしながら適正な凹凸 形状あるいは溝形状は不明であり，初期凝洞現象に関し ても十分な解明がなされているとはいいがたい．

そこで著者らは実操業への適用手段として，鋳型銅板 表面への微細溝加工をとりあげ検㗅することとした。 そ のためにまず鋳型への熱伀達の観点から，溝加l鋳型の 抜熱量低減の叮能性を解析した。つぎに試験連鋳機によ

昭和 60 年 4 月本会講演大会にて発表 昭和 61 年 5 月 9 日受付 (Received May 9, 1986)

* 住友金属工業 (株)総合技術研究所 (Technical Research Laboratories, Sumitomo Metal Industries, Ltd., 3 Oaza-Hikari Kashima-cho Kashima-gun Ibaraki pref. 314)

*2 住友金属工業 (株) 鹿鼠製鉄所（Kashima Steel Works, Sumitomo Metal Industries, Ltd.) 


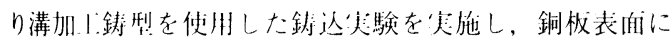

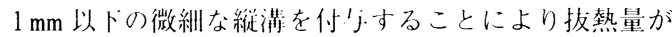
低減することを碓涊した ${ }^{14)}$ 。このような基礎的な検討

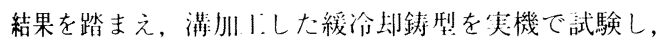
抜熱鼙の低減，凝湖シェル皆の均・化ならびに縦割れの 減少が汹机ることがわかつた。本報では，理論的検討絬

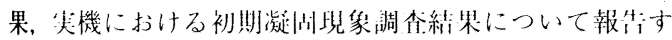
る.

\section{2. 理論的検討}

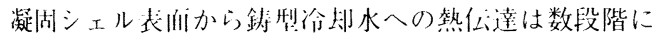

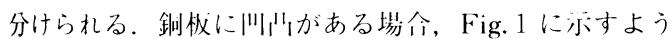

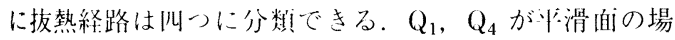

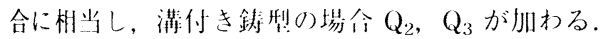

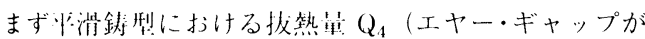
存在する場们について考えてみる ${ }^{15)} 、 Q_{4}$ は（1） 式であらわきれる。

$$
\mathrm{Q}_{\mathbf{4}}=h_{T}\left(T_{s}-T_{w}\right)
$$

$T_{S}$ は㠜湖シェル衣洎温度であり， $T_{w}$ は冷却水温度 である。総括锬伀辣倸数 $h_{r}$ は（2）式のようになる。 $h_{T}=\left(1 / h_{p}+1 / h_{a}+1 / h_{n}+1 / h_{m}+1 / h_{w}\right) \cdots(2)$ $h_{p}, h_{a}, h_{n}, h_{m}, h_{w}$ はそれぞれパウダーフィルム, エヤーギャップ，めつき艘，鋳型釦柲，鋳型一冷却水間 の熱伝造係数である. $h_{p}, h_{a}, h_{n}, h_{m}$ は $(3) \sim(6)$ 式でホさ机る。

$$
\begin{aligned}
& h_{p}=k_{p} / d_{p} \\
& h_{a}=k_{a} / d_{a}+4.88 /\left(\varepsilon_{n}^{-1}+\varepsilon_{p}^{-1}-1\right) \\
& {\left[\left\{\left(T_{p}+273\right) / 100\right\}^{4}-\left\{\left(T_{n}+273\right) / 100\right\}^{4}\right] /} \\
& \left(T_{\rho}-T_{n}\right) \\
& h_{n}=k_{n} / d_{n} \\
& h_{m}=k_{m} / d_{m}
\end{aligned}
$$

パウダーと鋳型が等食に接触している場合は，(2) 式に扒いて，エヤーギャップの面を無視す机ばよく，し

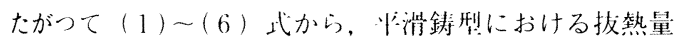

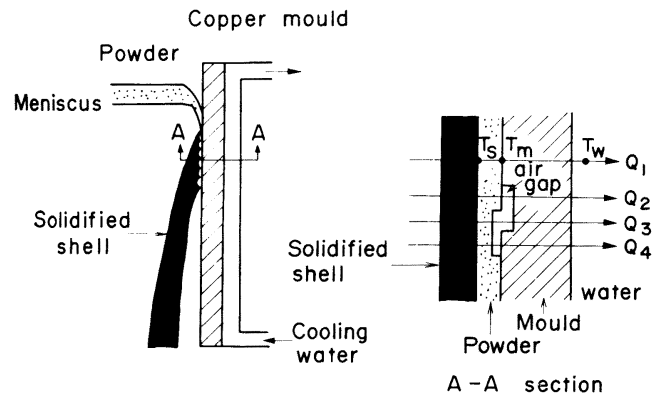

Fig. 1. Model of heat transfer in mould with grooves.
$\mathrm{Q}_{1} 、 \mathrm{Q}_{4}$ が算出できる。通常の鋳型内では， $\mathrm{Q}_{1}, \mathrm{Q}_{4}$ が ある比率を有していると考えられるため ${ }^{16)}$, 鋳型ーパウ ダー間の接触程度をあらわす, 非接触面積率 $Z_{p}$ と呼ぶ パラメーターを導入した. Table 1 に示す数值を用い て ${ }^{15)}$ ，平滑鋳型に扔ける $Z_{p}$ と抜熱量の関係を計算した 結果を Fig. 2 に示す。なお凝固シェル厚は, メニスカ スから $50 \mathrm{~mm}$ 下方で $2 \mathrm{~mm}$ と仮走した。通常の抜熱量 Qactual はメニスカス直下で $2.1 \times 10^{6} \mathrm{kcal} / \mathrm{m}^{2} \cdot \mathrm{h}$ と推定 されるので ${ }^{16) 17), ~ F i g . ~} 2$ から $Z_{p}$ は 0.6 と求まる.

つぎにツ凸処理を施した鋳型における抜熱量を求め た.ここで鋳型川部面積率 $Z_{m}$ を変化させ，また $Z_{p}=$ 0.6 , 山部のエヤーギャップは $60 \mu \mathrm{m}^{15)}$ とした. Fig. 3 に $Z_{m}$ と鋳型抜熱量の関係を示すが， $Z_{m}$ を 0.4 以上に すれば，通常の抜熱量の $2 / 3$ 以下に低減叮能であることが わかる.

したがつて溝加上鋳型において，微細溝によるエヤー ギャップの存在が重要であり，そのため溝の幅をできる だけ小さくして,パウダーの流入を防止する必要がある.

Table 1. Values used for calculation.

\begin{tabular}{l|l}
\hline$h_{w}$ & $23800 \mathrm{kcal} / \mathrm{m}^{2} \cdot \mathrm{h} \cdot{ }^{\circ} \mathrm{C}$ \\
$h_{b}$ & $1000 \mathrm{kcal} / \mathrm{m}^{2} \cdot \mathrm{h} \cdot{ }^{\circ} \mathrm{C}$ \\
$d_{m}$ & $0.028 \mathrm{~m}$ \\
$k_{m}$ & $319 \mathrm{kcal} / \mathrm{m} \cdot \mathrm{h} \cdot{ }^{\circ} \mathrm{C}$ \\
$d_{a}$ & $60 \mu \mathrm{m}$ \\
$k_{a}$ & $0.055 \mathrm{kcal} / \mathrm{m} \cdot \mathrm{h} \cdot{ }^{\circ} \mathrm{C}$ \\
$d_{p}$ & $300 \mu \mathrm{m}$ \\
$k_{p}$ & $3.0 \mathrm{kcal} / \mathrm{m} \cdot \mathrm{h} \cdot{ }^{\circ} \mathrm{C}$ \\
$d_{n}$ & $0.0005 \mathrm{~m}$ \\
$k_{n}$ & $60 \mathrm{kcal} / \mathrm{m} \cdot \mathrm{h} \cdot{ }^{\circ} \mathrm{C}$ \\
$\varepsilon_{m}$ & 0.3 \\
$\varepsilon_{p}$ & 0.9 \\
\hline
\end{tabular}

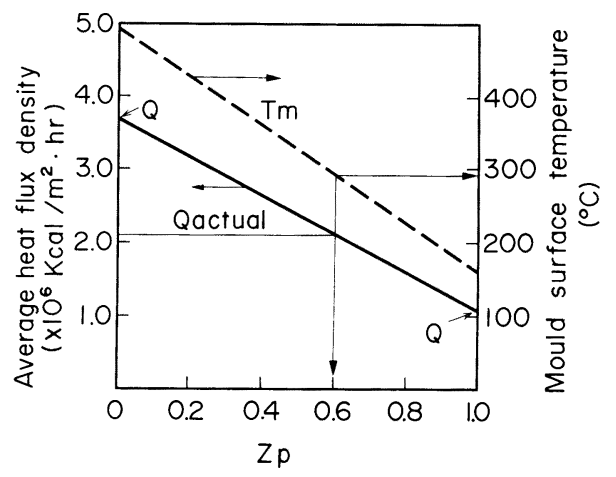

Fig. 2. Calculated result on relation between $Z_{p}$ and heat flux density. 


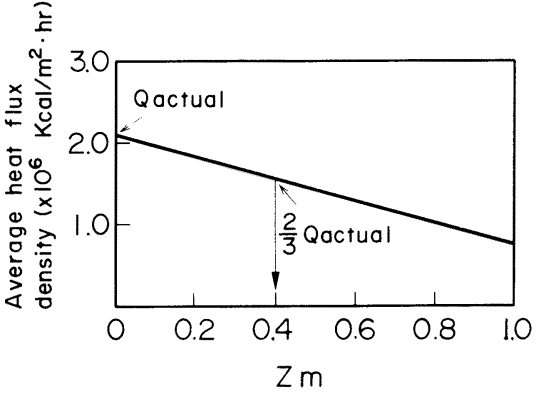

Fig. 3. Calculated result on relation between $Z_{m}$ and heat flux density.

\section{3. 試 験 方 法}

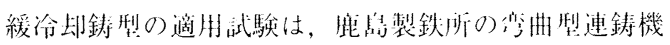

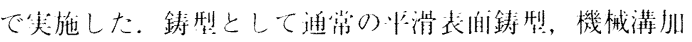

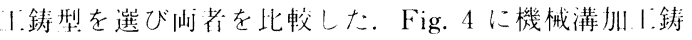

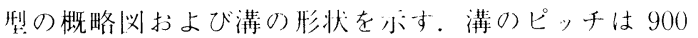
$\mu \mathrm{m}$ 漸の幅は $800 \mu \mathrm{m}$ であり，バウダーが流れこみにく

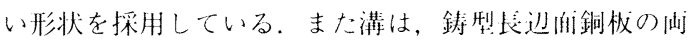
うに拟にした。

武験は主に撔板们けスラブで主施したため, Table 2 にホすごとく鋳僬速度は， $1.0 \mathrm{~m} / \mathrm{min}$ 以下である。

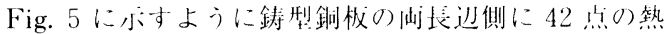

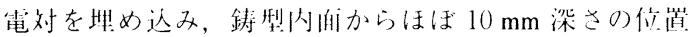

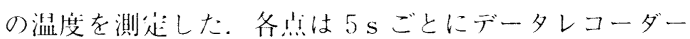

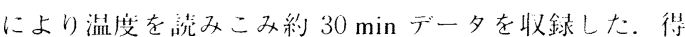
られた測温デー夕は, 統汁処埋をして, 怕均温度, 温度 变動, 性熱流果を求めた。

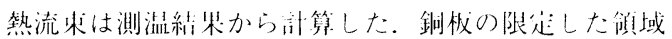

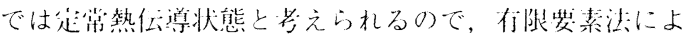
り 2 式元の埧度分们を（7)（9）式から求めた。

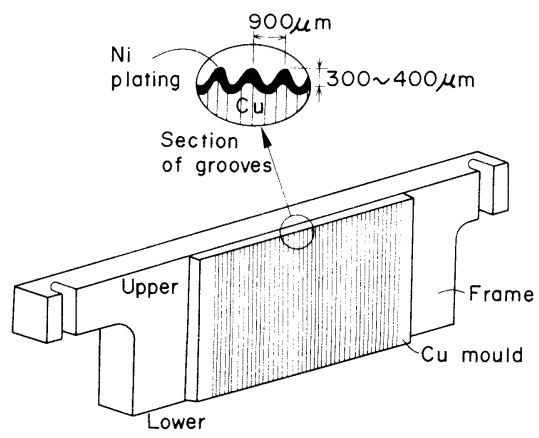

Fig. 4. Schematic illustration of mould with longitudinal grooves.

$$
\begin{aligned}
& \frac{\partial^{2} T}{\partial x^{2}}+\frac{\partial^{2} T}{\partial y^{2}}=0 \\
& Q=h_{w}\left(T_{m w}-T_{w}\right) \\
& Q=h_{b}\left(T_{m w}-T_{b}\right)
\end{aligned}
$$

\begin{tabular}{|c|c|}
\hline $\begin{array}{l}\text { Slab caster } \\
\text { Slab size } \\
\text { Steel grades } \\
\text { Casting speed } \\
\text { Condition of mould } \\
\text { inner surface }\end{array}$ & $\begin{array}{l}\text { No. } 1 \text { (C) machine at Kashima } 12.5 \mathrm{mR} \text { ) } \\
250 \mathrm{~mm} \text { thickness. } 1240 \text {.215 mm width } \\
\text { l.ow carbon, Middle carbon steel } \\
0.50-0.95 \mathrm{~m} / \mathrm{min} \\
\text { (1) Even (2) With grooves by machining }\end{array}$ \\
\hline
\end{tabular}

Table 2. Experimental condition.

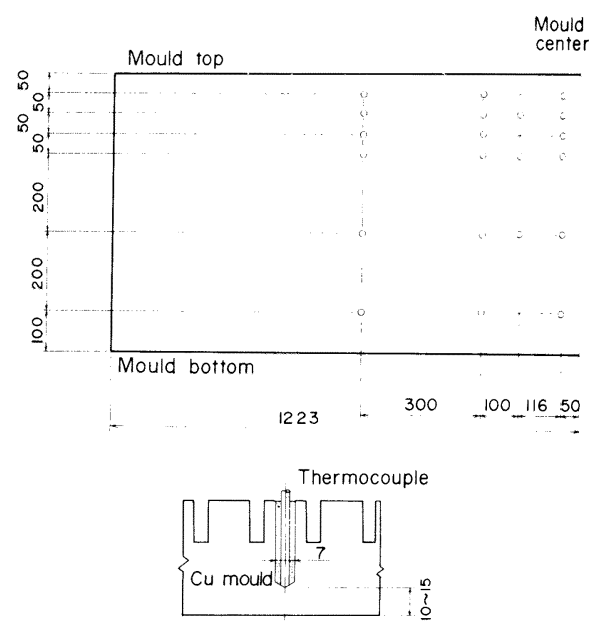

Fig. 5. Location of thermocouples in the copper mould.

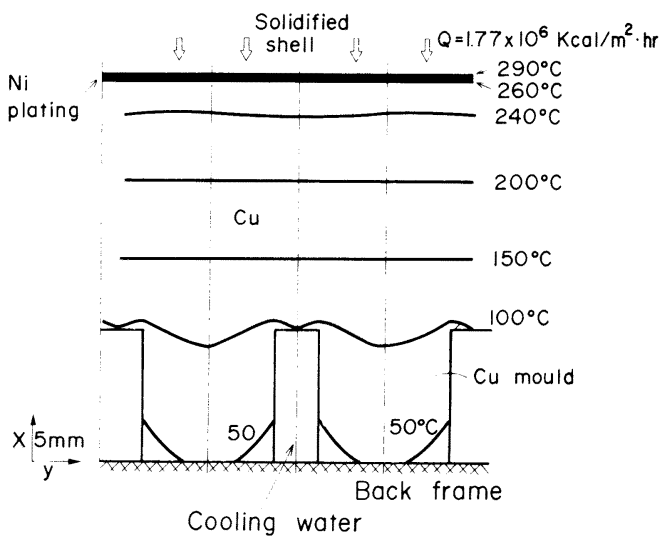

Fig. 6. Calculated temperature distribution in Cu mould. 

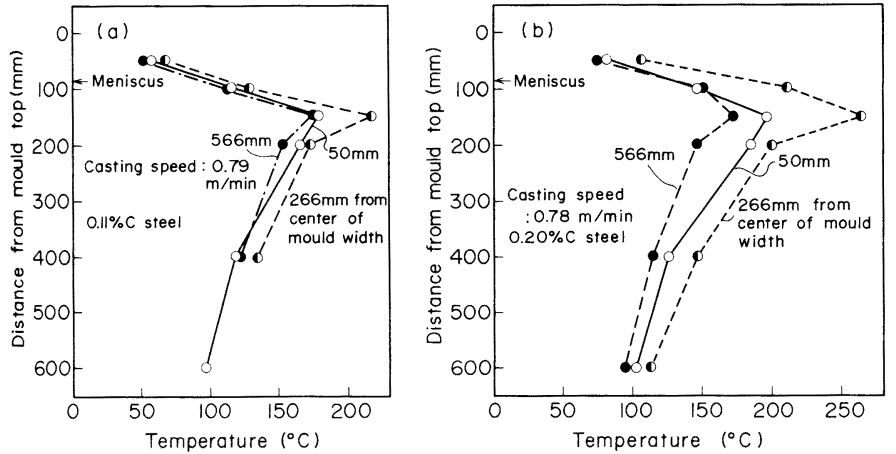

(a) Mild cooling mould with groove

(b) Conventional mould

Fig. 7. Measured temperature distribution in the mild cooling and the conventional mould.

（8）式，（9）式はそれぞれ鋳型と椧却水閒，鋳型と バックフレーム阔の哐界条件である。（7）（8）（9） 式拉よび Table 1 に小した数做を使用し，抜熱量 $Q$ を 变化させて滥度分们を求めた，Qが $1.77 \times 10^{6}$ $\mathrm{kcal} / \mathrm{m}^{2} \cdot \mathrm{h}$ の埸令について Fig. 6 に小すが, このよう にして，仕意の们崌に扔ける測温紏果から $Q$ を算出で きる。

鋳型内初期凝们シェル热は，鋳型内に $\mathrm{FeS}$ 老添加し， スラブの獚断向の+ルファープリントから測定した。微 少縦割机はスラブを伀洗後，その個数を測定した。

\section{4. 試験結果と考察}

\section{$4 \cdot 1$ 鋳型銅板測温結果および抜熱量}

通常鋳型，緩冷却鋳型それぞれの鈳极温度の鋳巡高さ

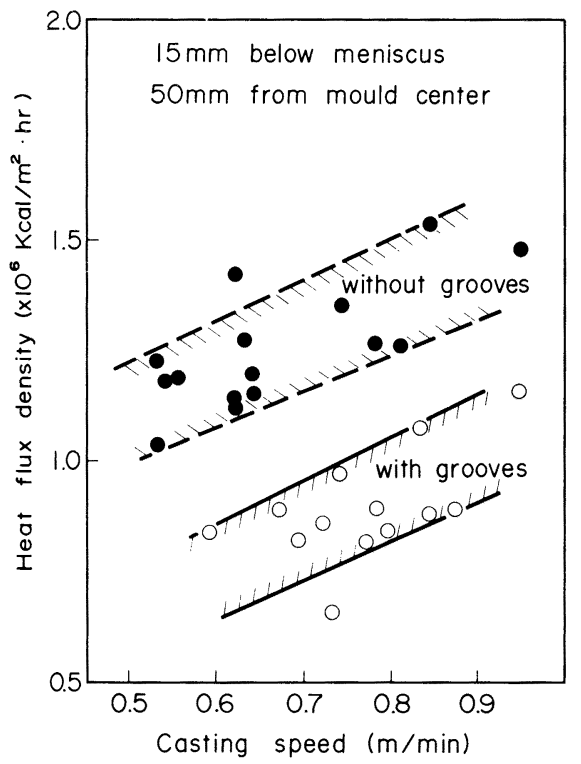

Fig. 8. Comparison of heat flux density between the mild cooling mould and the conventional mould.

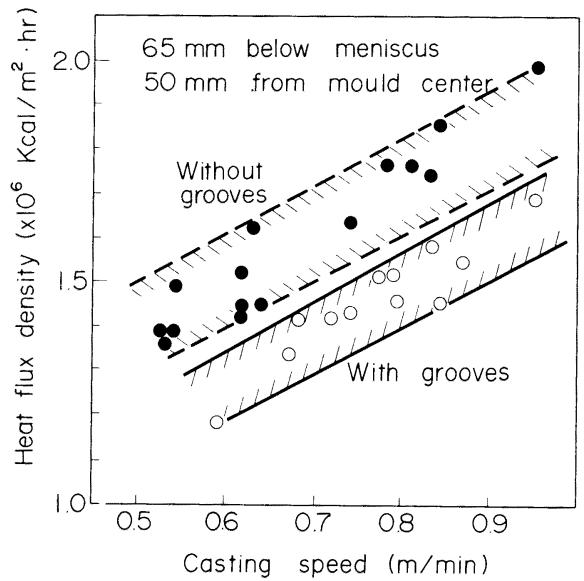

Fig. 9. Comparison of heat flux density between the mild cooling mould and the conventional mould.

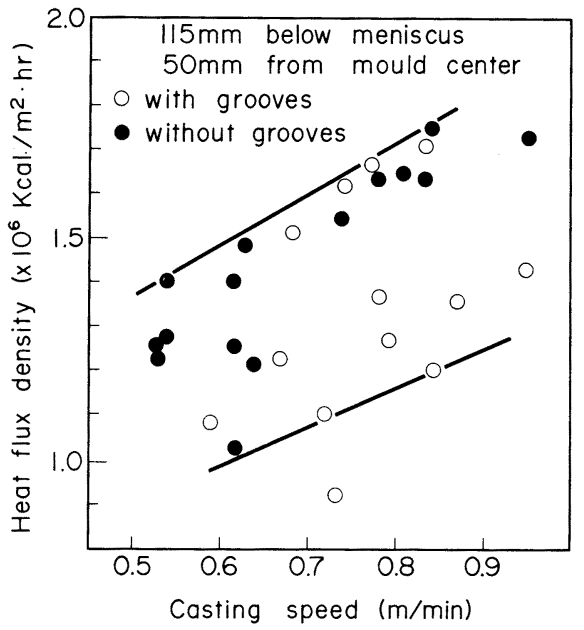

Fig. 10. Comparison of heat flux density between the mild cooling mould and the conventional mould. 

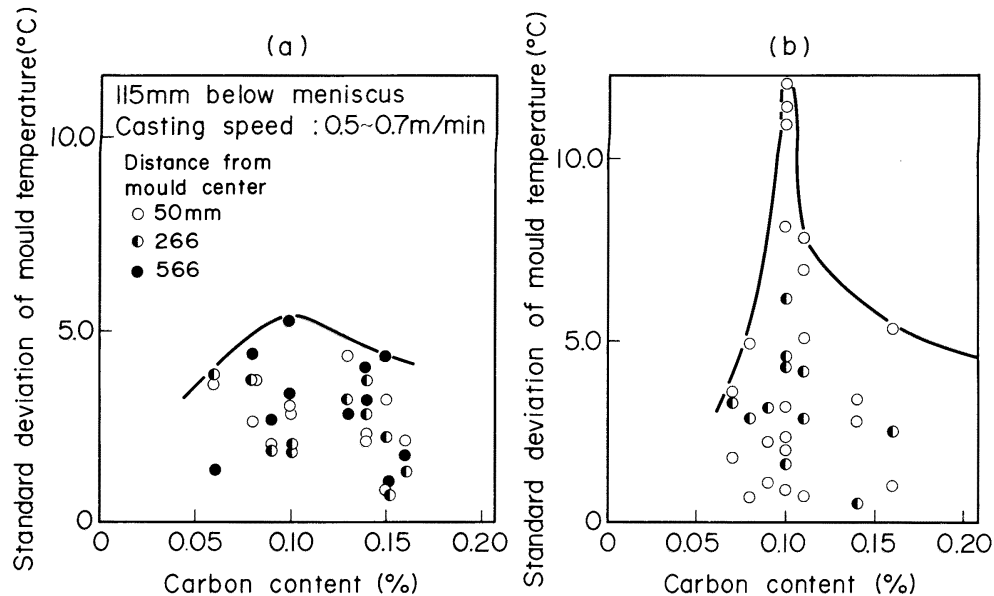

(a) Mild cooling mou!d with grooves (b) Conventional mould

Fig. 11. Relation beteen carbon content and mould temperature fluctuation in the moulds with or without grooves.
方向の分布をFig. 7 に示す.メニスカスより $65 \mathrm{~mm}$ 下 方で温度のピークが見られ，幅方向のばらつきは緩冷却 鋳型の方が少ない.またメニスカス近傍では緩冷却鋳型 の温度は低い。

$30 \mathrm{~min}$ の測温值を平均し, 鋳型への熱流束に変換し た結果を Fig. 8, 9, 10 に示す. 鋳型に溝がある場合と 平滑表面の両者を比較すると, メニスカスから $65 \mathrm{~mm}$ までは, 緩冷却鋳型のおが熱流束は低く, 特にメニスカ スから $15 \mathrm{~mm}$ の位置では，溝付鋳型の方が 30〜 40\%

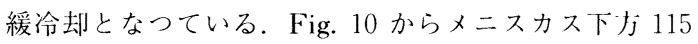
$\mathrm{mm}$ の位置における両鋳型の抜熱量は，ほとんど等しく なることがわかる.したがつて緩冷却鋳型はメニスカス 近傍で抜熱量の低下が大きく，モールド下方ではその差 は少ないことから, 初期凝阔シェルの均一化に対して望 ましいといえる.メニスカスから遠去かるにつれて, 緩 冷却鋳型と通常鋳型の抜熱量の差が縮まる理田は，鋳牌 が収縮することによりエヤーギャップが生成し，溝によ る断熱効果の寄与が小になるためと考えられる。

つぎに不均一凝阔の指標であり縦割れ発生につながる と考えられる鋳型銅板の温度変動 ${ }^{177)}$ を検封した。Fig. 11 は, メニスカス下 $115 \mathrm{~mm}$ の位莦に扔ける測温デー 夕から標準偏差を求め, 通常鋳型と緩冷却鋳型おのおの について比較したものである.崡鋳型ともに $0.10 \% \mathrm{C}$ 付近で温度变動が最も大きく，その傾们は通常鋳型にお いて顕著である。緩冷却鋳型の場合，温度变動は少なく， 通常鋳型の䄪 $1 / 2$ につている.

\section{$4 \cdot 2$ 初期凝固シェル厚}

Fig. 12 はサルファープリントから測定したシェル 厚，およびFig. 8〜10の垁測熱流束の妆均から訃算 したシェル厭を通常鋳型, 緩冷却鋳型で比較したもので

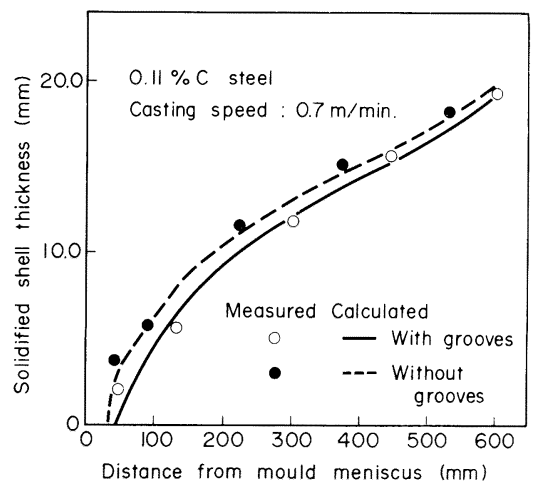

Fig. 12. Comparison of measured and calculated shell thickness within the mould length between the conventional mould and the mild cooling mould.

ある、緩冷却鋳型の場苓初期は凝沁シ.妅儿の発達が遅れ るが，鋳型出口では咑者の算は $0.5 \mathrm{~mm}$ となつて拀り。 ブレークアウトを助长する扩そ机はないと、合える。なお

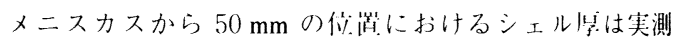
值のおが高くなつているが、こ机はメニスカス近傍では 2 次无的な熱伝導になつて抢り ${ }^{1718)}$, 尖際の报熱量は 計算に使用した做より点くなつているためと推缹され 万.

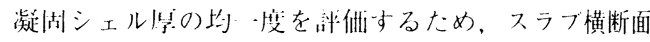
幅方们に $100 \mathrm{~mm}$ ごとにシェル罗を测起し、その槽準偏 差を求めた。Fig. 13 に通常鋳型と緩冷却鋳型について

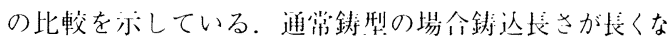
るにつ机て、シェル珰の不均・度は增㺫するが, 緩冷却 鋳型の場令，不均度は低く，しかも鋳型们側近傍にお いても，通常鋳型の1/2の不坋小度である。 


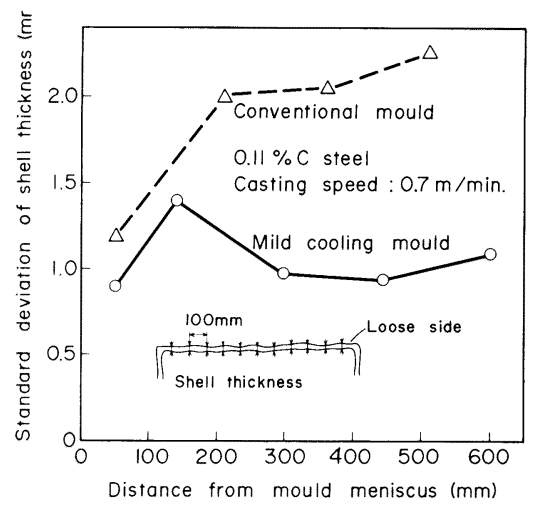

Fig. 13. Comparison of shell thickness variarance in the transverse section of slabs cast by the conventional mould and the mild coolimg mould.

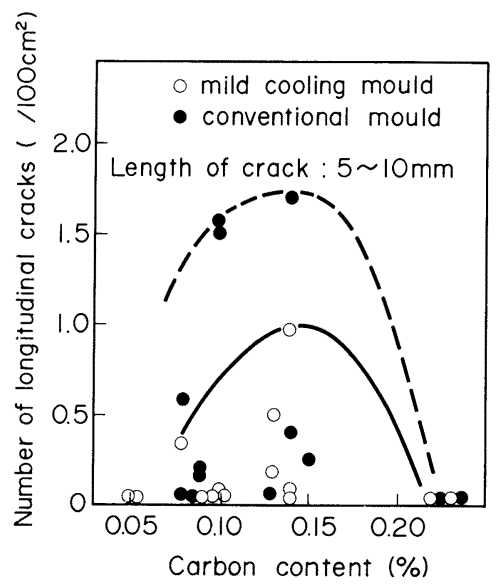

Fig. 14. Effect of mild cooling in mould on occurrence of small longitudinal cracks.

\section{$4 \cdot 3$ 微少縦割れ}

鋳蛊速度が $1.0 \mathrm{~m} / \mathrm{min}$ 以卜の埸全大きな縦割れ発生 頻度は低いので，微少縦制れ（咬さ：5〜10 mm）に着

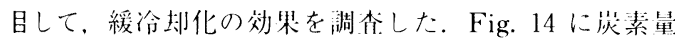
と微少縦制机做数の関倸を小吋。 0.10 - $0.15 \% \mathrm{C}$ で縦 割れ発少:頻度が人きくなつているが、緩泠却化により割 れは約斗分に減少している。

\section{$4 \cdot 4$ 微細溝へのパウダー侵入}

溝を微紼に扠にした緩冷却鋳型に扔いて，緩冷却化の ためには暳部のエヤーギャップを確你することが必要で

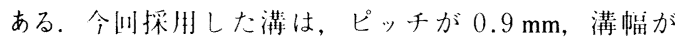
$0.8 \mathrm{~mm}$ であるが，パウダーが鋳にどれだけ侵人してい るかは不明であり，そこで伀熟湆算により推定すること を試みた。
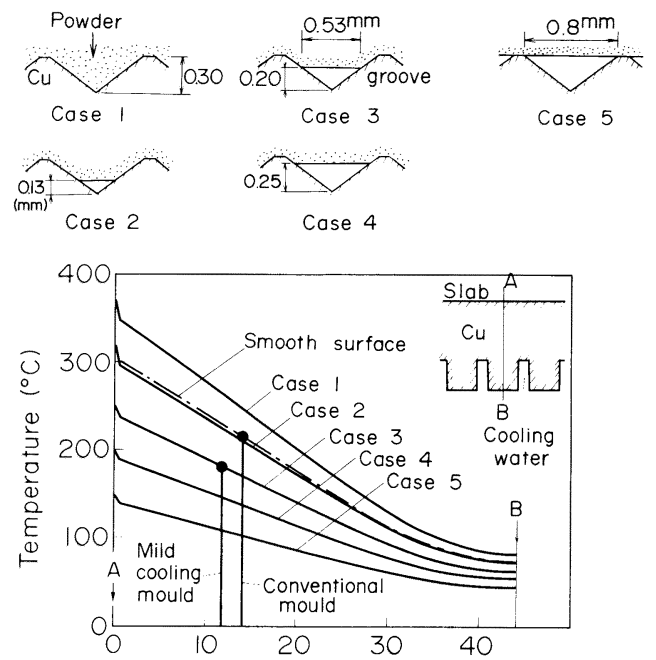

Distance from mould inner surface $(\mathrm{mm})$

Fig. 15. Calculated result of temperature distribution in copper mould in regard to penetration of powder into groove.

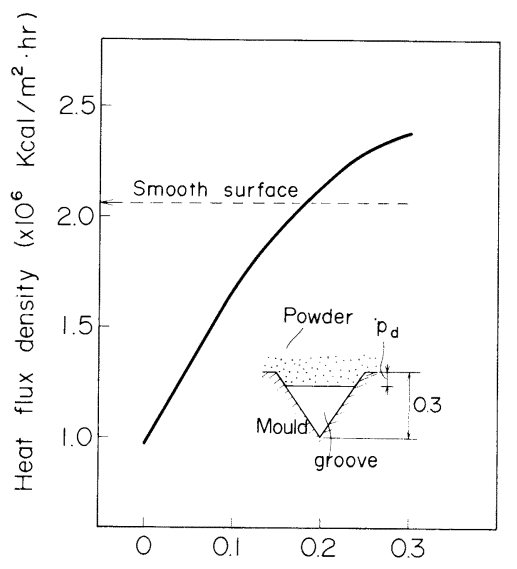

Penetration depth of powder, $p_{d}(\mathrm{~mm})$

Fig. 16. Effect of powder penetration into groove on heat flux density.

Fig. 15 に羊すように，パウダーが，深さ $0.3 \mathrm{~mm}$ の 溝中に，すべて侵入している場合をケース 1 ，全く侵入 していない場合をケース 5 とし，侵入程度を 5 段階に分 けて,おのおのについて 2 次元の伝熱計算をおこなつた。

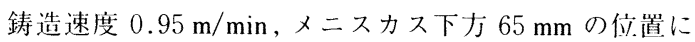
おける銅板温度に合致するようにままず平滑鋳型におい て抜熱量を沈资し，つぎに溝部のエヤーギャップ深さを 考虑して伝熱計算をおこない, 銅板厚み力们の温度分布 を求めた。結果を Fig. 15 に示すが, 緩冷却鋳型に扔け 
る温度実測値から判断して，パウダー侵入はケース 3 に 相当する.すなわち溶融パウダーは, $0.1 \mathrm{~mm}$ 溝内に人 つて扔りこの場合溝幅は $0.53 \mathrm{~mm}$ である。したがつ てこの結果から，パウダーがまつたく侵人しない限界溝 幅は、打打よそ $0.5 \mathrm{~mm}$ と推定される。

间様の計算から，パウダー侵人深さ $P_{d}$ と抜熱量の関 係を求めたのが Fig. 16 である。斗滑表面鋳型の場苓, 抜熱量は $2.05 \times 10^{6} \mathrm{kcal} / \mathrm{m}^{2} \cdot \mathrm{h}$ であり，溝加l鋳型にお いて $P_{d}=0.1 \mathrm{~mm}$ では $1.66 \times 10^{6} \mathrm{kcal} / \mathrm{m}^{2} \cdot \mathrm{h}$ となる。ま た溝中にすべてパウダーが侵人すると，伝熱の界佰積が 增え, 平滑表面鋳型の抜熱量以上の值が得られ，强冷却 効果を在することがわかる.

したがつて緩冷却化のためには，溝幅を $0.5 \mathrm{~mm}$ 以下 としてパウダーを侵入させないようにするか，あるいは 溝幅が $0.5 \mathrm{~mm}$ 以上であつても溝の深さを大きくして, パウダーが侵人しても，十分なエヤーギャップを確保す る必要がある。

\section{5. 結}

言

連続鋳造スラブの表面縦割れの原内となる鋳型内初期 凝固シェル不均一度を改善するため，緩冷却鋳型を検討 した。

1)理論的検討により鋳型内表面に山川処理をすれ ば，屽部のエヤーギャップの断熱効果により緩冷却化が 叮能であることが判明した。

2）実用的には，鋳型銓板内面に，溝幅 $800 \mu \mathrm{m}$ の微 細縦溝を機械加「にし，厚板用スラブ連鋳機での試験をお こない，抜熱量，銅板の温度変動，凝闹シェル厚抢よび 微少縦割れについて，通常の平滑表百鋳型と比較した。 その結果，抜熱量は特にメニスカス近傍に打いて，30 $40 \%$ 減少することを確認した。メニスカスから $115 \mathrm{~mm}$ 以上下方では，雨鋳型の抜熱量はほとんど差はみられな かつた。

3 ）銅板の温度变動，および凝固シェル怛の不均一度

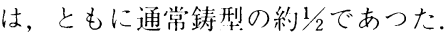

4 ) 微少縦割机も減少傾问を示し, 品質改善効果を有 する。

5 ）パウダーが侵入しない限界溝幅は，約 $0.5 \mathrm{~mm} て ゙$ あると推定される。

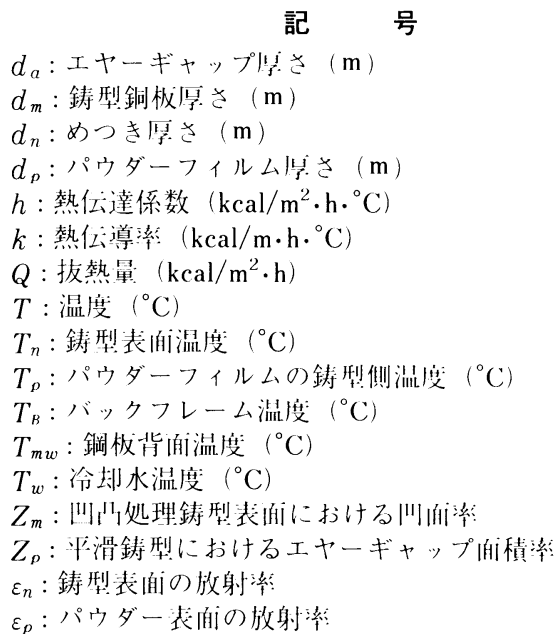

\section{文献}

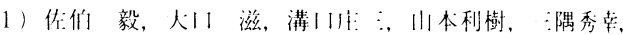
常葥 聡: 鉄と鋼, 68 (1982)，p. 1773

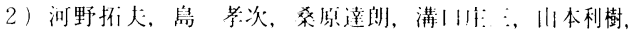

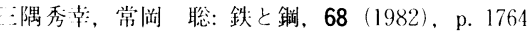

$3) \quad J . K$. Brimacombr, $F$. Whinib:Ro and $E$. B. Hawbolt: Metall. Trans., 10B (1979), p. 279

4) S. N. SinciH and K. E. Bı.Aztk: J. Met., 26 (1974), p. 17

5 ) A. GRII.I and J. K. Brimacomist: Ironmaking Steelmaking, 3 (1976), p. 76

6 ）杉行泰大，中村此行：鉄と针，65 (1979)，p. 1702

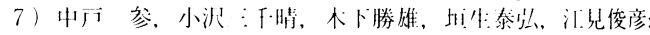
鉄と鎆，67 (1981)，p. 1200)

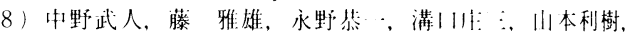
浅野敬輔：鉄と䤱，67（1981），p. 1210

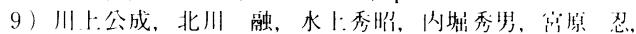

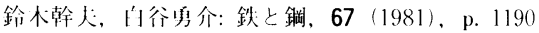

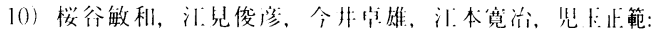
鉄と镃，67 (1981), p. 1220

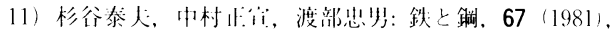
p. 1508

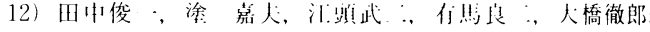
鉄と铜，68 (1982)，S 159

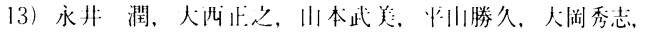
藤川奉郎：鉄と銅，69 (1983)，S158

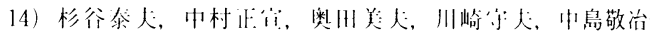
鉄と䠃，70（1984），S921

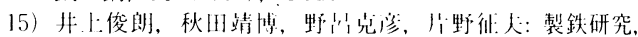
293 (1978), p. 34

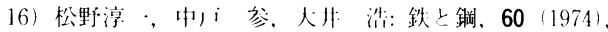
p. 1023

17) E. Takelchi and J. K. Brimacombe: Metall. Trans., 15B (1984), p. 493

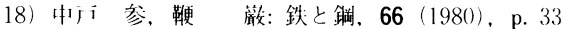

